\title{
Awareness of antibiotic prescription for endodontic therapies - comparative survey between interns, post graduates and general dental practitioners
}

\author{
S. Anitha Rao ${ }^{1}$, K. Santhosh Reddy ${ }^{2, *}$, M. Sandeep ${ }^{3}$, C. S. Soonu ${ }^{4}$ \\ ${ }^{1}$ Reader, ${ }^{2-3}$ Post Graduate, ${ }^{4}$ Professor, ${ }^{1-4}$ Dept. of Conservative Dentistry and Endodontics, Mamata Dental College, Khammam, \\ Telangana, India
}

*corresponding Author:

Email: santhoshreddy.k11@gmail.com

\begin{abstract}
Objectives: To evaluate the awareness of interns, post graduates and general dental practitioners on antibiotic prescribing for endodontic conditions.

Materials and Methods: A questionnaire was conducted among 20 General Dental Practitioners, 40 Postgraduate students and 60 Interns of Mamata Dental College, Khammam. Questionnaire consisted a total of 20 questions. It recorded general information such as dental school where they were graduated, number of patients seen each working day, number of endodontic emergency patients and awareness of available antibiotic prescribing guidelines for endodontic therapies.

Results: Amoxicillin was the most prescribed antibiotic for patients without allergic towards penicillin. The first choice for patients allergic towards penicillin was clindamycin. The combination of amoxicillin and clavulanic acid was considered to be the first antibiotic of choice for more serious acute apical abscess cases, including life threatening conditions. General dental practitioners were aware of the guidelines for prescribing antibiotics for endodontic conditions when compared to the post graduate students and interns.

Conclusion: The dental professionals should be aware of rationalization of antibiotic use and antibiotic prescription for endodontic infections, consequences of their overuse and antibiotic resistance.
\end{abstract}

Keywords: Questionnaire, Amoxicillin, Clindamycin, Clavulanic acid, Rationalization, Antibiotic resistance.

\section{Introduction}

In dentistry the main reason for the development of resistant bacterial species is the misuse of antibiotics, which leads to the current global antibiotic resistance crisis. ${ }^{1}$ Antibiotics can be used for prophylaxis during invasive dental procedures in endodontics for patients with specific health conditions following a risk assessment. $^{2}$

Antibiotics were used only. An adjunct to definitive non-surgical or surgical endodontic therapy. ${ }^{3}$ For patients who have systemic signs and symptoms associated with endodontic infections, antibiotic therapy should be reserved. ${ }^{4}$

The student group can provide evidence on what is learnt and assimilated during their education which will be applied in their professional life. General dental practitioners represent professionals who are subjected to various environmental factors, such as working time pressure that has been described as one of the factors for inappropriate prescription of antibiotics. ${ }^{6}$

Therefore, this study is aimed to evaluate the views of interns, post graduates and general dental practitioners on antibiotic prescribing for endodontic conditions.

\section{Material and Methods}

The present study was conducted in Department of Conservative dentistry and Endodontics, Mamata dental college, Khammam.

1. A questionnaire was conducted among 20 General DentalPractitioners, 40 Postgraduate students and 60 Interns of MamataDental College, Khammam.

2. Questionnaire consisted a total of 20 questions (Fig. 1 and 2) 


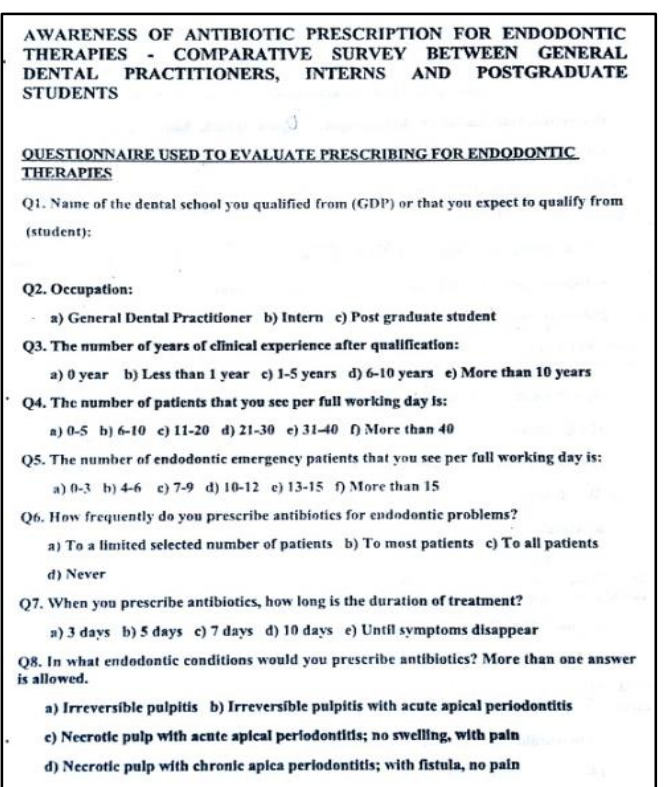

Fig. 1

It recorded general information such as dental school where they were graduated, number of patients seen each working day, number of endodontic emergency patients and awareness of available antibiotic prescribing guidelines for endodontic therapies.

Statistical analysis was done by using chi- square, kruskal-wallis test. Difference of $\mathrm{p} \leq 0.05$ or more was considered significant,data obtained was expressed as Mean \pm SD.

\section{Results}

Amoxicillin was the most prescribed antibiotic for patients without allergic towards penicillin among all the groups (Table 5 and Fig. 7). The first choice for patients allergic towards penicillin was clindamycin among all the groups (Table 1 and Fig. 3).The general

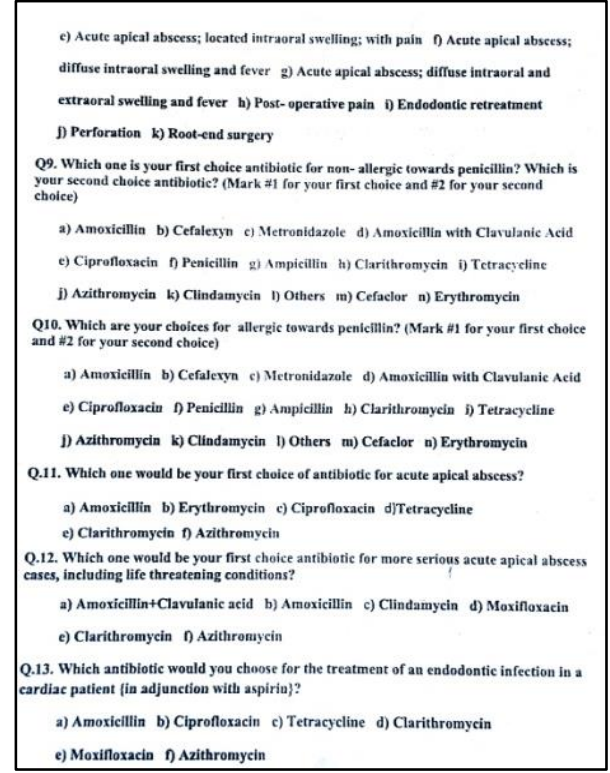

Fig. 2

dental practitioners and post graduate students were more aware of the prescription of antibiotics for endodontic infections and prescribed antibiotics to limited number of patients when compared to other groups (Table 4 and Fig. 6). The combination of amoxicillin and clavulanic acid was considered to be the first antibiotic of choice formore acute apical abscess cases, including life threatening conditions prescribed by all the three groups (Table 2 and Fig. 3). General dental practitioners were moreaware of the guidelines for prescribing antibiotics for endodontic conditions when compared to the post graduate students and interns (Table 3 and Fig. 5).

\section{Table 1}

\begin{tabular}{|l|c|c|c|c|}
\hline & Clindamycin & Tetracycline & Azithromycin & Others \\
\hline $\begin{array}{l}\text { General dental } \\
\text { practitioners }\end{array}$ & 14 & & 4 & 2 \\
\hline $\begin{array}{l}\text { Post graduate } \\
\text { students }\end{array}$ & 26 & & 12 & 2 \\
\hline Interns & 24 & 7 & 15 & 14 \\
\hline
\end{tabular}

Fig. 3

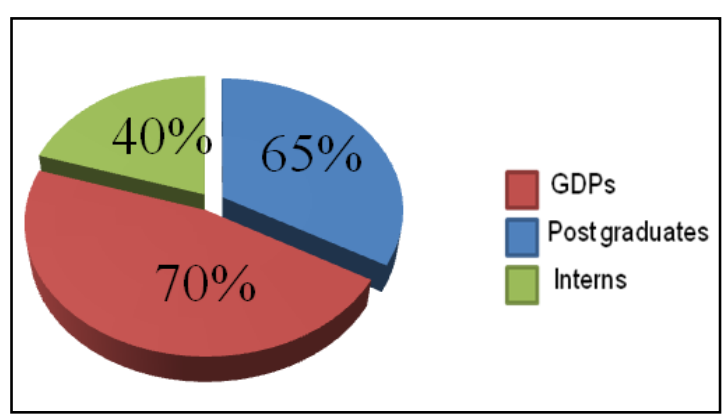


Table 2

\begin{tabular}{|l|c|c|c|c|}
\hline & $\begin{array}{c}\text { Amoxicillin with } \\
\text { clavulanic acid }\end{array}$ & $\begin{array}{c}\text { Amoxic } \\
\text { illin }\end{array}$ & Clindamycin & Others \\
\hline $\begin{array}{l}\text { General dental } \\
\text { practitioners }\end{array}$ & 20 & & & 8 \\
\hline $\begin{array}{l}\text { Post graduate } \\
\text { students }\end{array}$ & 32 & & & 14 \\
\hline Interns & 36 & 6 & 4 & \\
\hline
\end{tabular}

\section{Fig. 4}

\section{Table 3}

\begin{tabular}{|l|c|c|}
\hline & Yes & No \\
\hline General dental practitioners & 18 & 2 \\
\hline Post graduate students & & 16 \\
\hline Interns & 24 & 36 \\
\hline
\end{tabular}

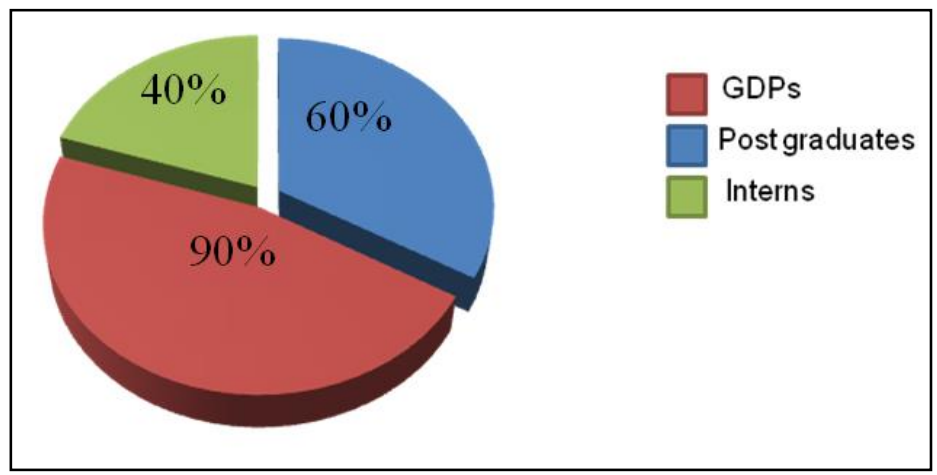

Fig. 5

Table 4

\begin{tabular}{|l|c|c|c|c|}
\hline & $\begin{array}{c}\text { Limited no of } \\
\text { patients }\end{array}$ & $\begin{array}{c}\text { To most } \\
\text { patients }\end{array}$ & To all patients & Never \\
\hline $\begin{array}{l}\text { General dental } \\
\text { practitioners }\end{array}$ & 16 & 4 & & 2 \\
\hline $\begin{array}{l}\text { Post graduate } \\
\text { students }\end{array}$ & 26 & 8 & 4 & 2 \\
\hline Interns & 22 & 32 & 4 & 2 \\
\hline
\end{tabular}




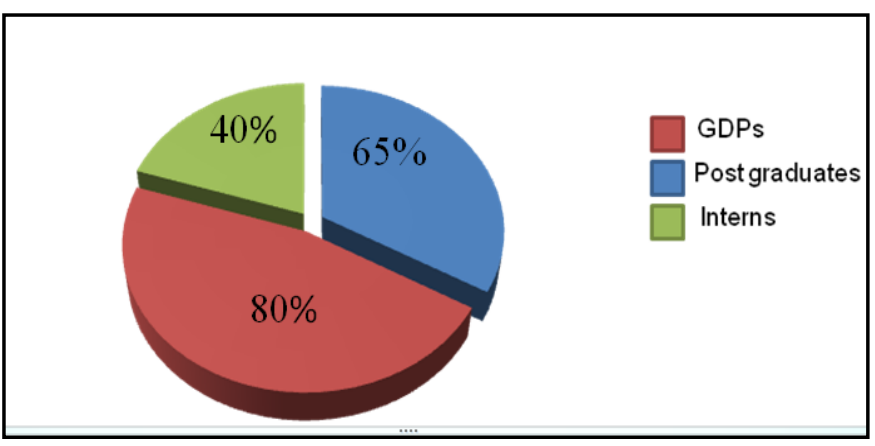

Fig. 6

Table 5

\begin{tabular}{|l|c|c|c|c|}
\hline & Amoxicillin & Azithromycin & $\begin{array}{c}\text { Amoxicillin with } \\
\text { clavulanic acid }\end{array}$ & Others \\
\hline $\begin{array}{l}\text { General dental } \\
\text { practitioners }\end{array}$ & 18 & & 2 & \\
\hline $\begin{array}{l}\text { Post graduate } \\
\text { students }\end{array}$ & 30 & & 5 & 5 \\
\hline Interns & 36 & 4 & 12 & 8 \\
\hline
\end{tabular}

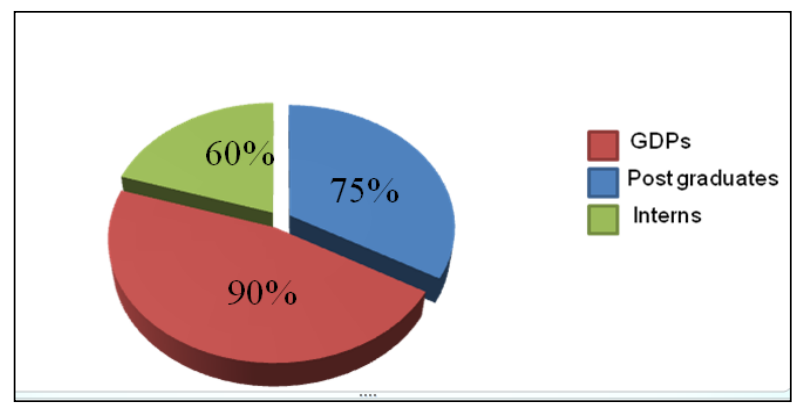

Fig. 7

\section{Discussion}

The present study was based on a questionnaire answered by 20 general dental practitioners, 40 post graduate students and 60 interns from Mamata Dental College, Khammam evaluated the prescription of antibiotics for endodontic therapies. The general information such as dental school where they were graduated number of patients seen each working day number of endodontic emergency patients and awareness of available antibiotic prescribing guidelines for endodontic therapies have been recorded.

In endodontic, antibiotics should be used only as an adjunct to definitive nonsurgical or surgical endodontic therapy. ${ }^{3}$ Inappropriate prescription and excessive use of antibiotics are major contributing factors in the emergence of antibiotic resistance. ${ }^{5-10}$ The ideal duration of antibiotic treatment should be the shortest capable of preventing both clinical and microbiological relapse. Prescription of antibiotics should be made initially for a 2-3 or 5-day period because most acute infections resolve within 3-7 days. ${ }^{11}$
In irreversible pulpitis with acute apical periodontitis, antibiotics are not indicated as the pulp remains. There is no infection or signs and symptoms of systemic involvement. ${ }^{12}$ In the present study, amoxicillin was the most prescribed antibiotic for patients without allergic towards penicillin. ${ }^{13,14}$ The first choice for patients allergic towards penicillin was clindamycin. Erythromycin, a macrolide, could be considered an option for patient's allergic to penicillin as it has similar activity spectrum to penicillin. Amoxicillin and clavulanic acid combination is prescribed as amoxicillin is susceptible to degradation by b-lactamase producing bacteria for life threatening conditions. ${ }^{15,16}$

In the present study a small percentage of post graduate students and interns stated that they would never prescribe antibiotics and this could be a misinterpretation of the questions or a lack of knowledge because they are not licensed to prescribe antibiotics at this stage of their training. The optimal dosage of antibiotics should be prescribed enough with minimal adverse effects on the physiology of the host and microbial ecology with efficient elimination 
of pathogens. The results of this study revealed that more than a third of post graduate students and a large proportion of interns were not aware of the various guidelines.

\section{Conclusion}

The dental professionals should be aware of rationalization of antibiotic use and antibiotic prescription for endodontic infections, consequences of their overuse and antibiotic resistance.

\section{References}

1. O'Neill J tackling drug-resistant infections globally: final report and recommendations. London: WellcomeTrust \& HM Government. 20016;1-80.

2. Wilson W, Taubert KA, Gewitz M et al. Prevention of infective endocarditis guidelines from the American Heart Association: a guideline from the American Heart Association Rheumatic Fever, Endocarditis, and Kawasaki Disease Committee, Council on Cardiovascular Disease in the Young, and the Council on Clinical Cardiology Council on Cardiovascular Surgery and Anesthesia, and the Quality of Care and Outcomes Research Interdisciplinary Working Group. Circ J. 2007; 116:1736-54.

3. Rodriguez-Nunez A, Cisneros-Cabello R, VelascoOrtega E, Llamas-Carreras JM, Torres-Lagares D, Segura-Egea JJ Antibiotic use by members of the Spanish Endodontic Society. J Endod. 2009;35:1198203.

4. Jacinto RC, Montagner F, Signoretti FGC, Almeida GC, Gomes BPFA Frequency, microbial interactions, and antimicrobial susceptibility of Fusobacterium nucleatum and Fusobacterium necrophorum isolated from primary endodontic infections. J Endod. 2008;34:1451-56.

5. Segura-Egea JJ, Velasco-Ortega E, Torres-Lagares D, Velasco-Ponferrada MC, Monsalve-Guil L, LlamasCarreras JM Pattern of antibiotic prescription in the managementof endodontic infections amongst Spanish oral surgeons. Int Endod J. 2010;43:342-50.

6. Cope AL, Francis NA, Wood F, Chestnutt IG (2015) Antibiotic prescribing in UK general dental practice: a cross-sectional study. Community Dent and Oral Epidemiol. 2015;44:145-53.

7. Whitten BH, Gardiner DL, Jeansonne BG, Lemon RR Current trends in endodontic treatment: report of a national survey. J Am Dental Association. 1996;127;1333-41.

8. Yingling NM, Byrne BE, Hartwell GR Antibiotic useby members of the American Association of Endodontistsin the Year 2000: report of a national survey. J of Endod. 2002;28:396-404.

9. Carl Llor, Lars Bjerrum Antimicrobial resistance: risk associated with antibiotic overuse and initiatives to reduce the problem. Ther Adv Drug Saf. 2014;5(6):229-41.

10. Palmer NAO, Pealing R, Ireland RS, Martin MV Therapeutics: a study of prophylactic antibiotic prescribing in National Health Service general dental practice in England. British Dental J 2000;189:43-6.

11. Oberoi SS, Dhingra C, Sharma G, Sardana D Antibiotics in dental practice: how justified are we. Int Dental J. 2015;65: 4-10.

12. Nagle D, Reader A, Beck M, Weaver J Effect of systemic penicillin on pain untreated irreversible pulpitis. Oral Surgery Oral Med Oral Pathology Oral Radiol and Endod. 2000;9:636-40.

13. Skucaite N, Peciuliene V, Maneliene R, Maciulskiene $\mathrm{V}$, Antibiotic prescription for the treatment of endodontic pathology: a survey among Lithuanian dentists. Med (Kaunas). 2010;46:806-13.

14. Castilho L, Paixao HH, Perini E, Prescription patterns of drugs of systemic use by dentists. Rev de SaudePublica. 1999;33:287-94.

15. Barcelona L, Marın M, Stamboulian D Betalactam antibiotics combined with bectalactamases inhibitors. Amoxicillin-sulbactam. Medicina (B Aires). 2008;68: 65-74.

16. Montagner F, Jacinto RC, Correa Signoretti FG, Scheffer de Mattos V, Grecca FS, Gomes BP, Betalactamic resistance profiles in Porphyromonas, Prevotella, and Parvimonas species isolated from acute endodontic infections. J of Endod. 20014;40:339-44. 
